\title{
Preoperative renal impairment and off-pump coronary artery bypass grafting: The jury is still out
}

\author{
Mustafa Zakkar, FRCS, and Gianni D. Angelini, FRCS
}

From the Bristol Heart Institute, Bristol University, Bristol, United Kingdom.

Disclosures: Authors have nothing to disclose with regard to commercial support.

Received for publication March 25, 2018; accepted for publication March 28, 2018; available ahead of print May $17,2016$.

Address for reprints: Gianni D. Angelini, FRCS, Bristol Heart Institute, Bristol Royal Infirmary, Bristol BS28HW,

United Kingdom (E-mail: g.d.angelini@bristol.ac.uk).

J Thorac Cardiovasc Surg 2018;156:974-5

$0022-5223 / \$ 36.00$

Crown Copyright $\odot 2018$ Published by Elsevier Inc. on behalf of The American Association for Thoracic Surgery https://doi.org/10.1016/j.jtcvs.2018.03.140

The superiority of off-pump or on-pump coronary artery bypass grafting $(\mathrm{CABG})$ remains to be demonstrated. Through the years, retrospective and prospective studies have suggested that off-pump CABG is associated with improved outcomes, such as reduced renal injury, reduced bleeding and need for transfusion, and shortened hospital stay. The Randomized On/Off Bypass trial, however, demonstrated that off-pump CABG led to lower 5-year survival and event-free survival than did on-pump CABG. ${ }^{1}$ The more robust CABG Off or On Pump Revascularization Study, in contrast, showed that the rate of the composite outcome of death, stroke, myocardial infarction, renal failure, or repeat revascularization at 5 years of follow-up was similar between patients who underwent off-pump CABG and those who underwent on-pump CABG. ${ }^{2}$

Preoperative renal impairment had been shown to affect outcomes after cardiac surgery. In fact, the report from the Society of Thoracic Surgeons national database on patients undergoing $\mathrm{CABG}$ showed that preoperative renal disease is common in patients undergoing $\mathrm{CABG}$ and that early mortality and morbidity after $\mathrm{CABG}$ rise inversely with declining preoperative renal function. ${ }^{3}$ Furthermore, the euroSCORE II includes renal impairment, as measured by creatinine clearance, as one of the risk factors for adverse outcomes after surgery. ${ }^{4}$ We have demonstrated previously that preoperative mild renal impairment is an independent risk factor for mortality in patients undergoing cardiac surgery. 5,6

In this issue of the Journal, Ueki and colleauges ${ }^{7}$ report their elegant retrospective study from the Japan Cardiovascular Surgery Database of 38,051 patients with preoperative renal impairment who underwent primary nonemergency isolated CABG from 2013 to 2015. Patients were stratified into 4 categories according to their estimated glomerular filtration rate (eGFR). The clinical outcomes were compared between patients undergoing off-pump ( $n=23,634)$ and on-pump CABG in each stratum. The study demonstrated that in patients with mildly reduced renal function (eGFR of $60-89 \mathrm{~mL} / \mathrm{min} / 1.73 \mathrm{~m}^{2}$ ), there

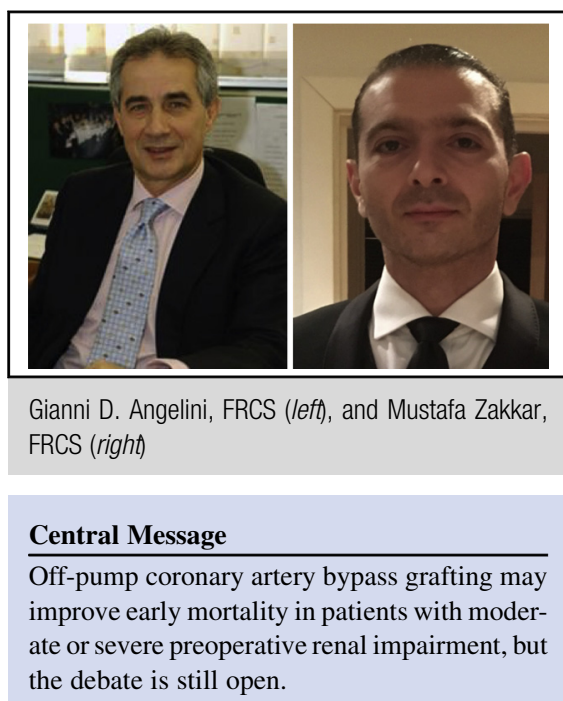

See Article page 976.

was no significant risk reduction effect of off-pump CABG for operative mortality. Conversely, in patients with moderate or severe renal disease (eGFR of $<60 \mathrm{~mL} / \mathrm{min} / 1.73 \mathrm{~m}^{2}$ ), off-pump CABG was associated with a significantly lower incidence of operative death. In addition, in patients with severe renal disease (eGFR of $<30 \mathrm{~mL} / \mathrm{min} / 1.73 \mathrm{~m}^{2}$ ), off-pump CABG was associated with a significantly lower incidence of de novo dialysis.

The preoperative characteristics of the cohort of patients included in this study are quite striking. Not only did more than $97 \%$ of patients undergoing isolated CABG have at least mild renal failure, they also had such other risk factors as diabetes, preoperative dialysis, and mean serum creatinine level of $1.7 \mathrm{mg} / \mathrm{dL}$. It is not clear when the eGFR was estimated in relation to the timing of surgery or angiography. Furthermore, the article of Ueki and colleagues ${ }^{7}$ is limited by the absence of long-term follow-up, mainly in terms of mortality and repeated revascularization. This may be particularly relevant given that the off-pump CABG group had a significantly lower number of distal anastomoses and that there were differences in the use of multiarterial grafts. Ueki and colleagues ${ }^{7}$ concluded that off-pump CABG significantly reduced operative mortality in patients with moderate or severe preoperative renal dysfunction but not in those with mild preoperative renal dysfunction. This article supports previous published evidence that off-pump CABG can be associated with reduced short-term complications in a select population. It remains 
to be seen, however, whether this translates to long-term improvement or whether such results can be reproduced in a Western population with a different risk profile.

\section{References}

1. Shroyer AL, Hattler B, Wagner TH, Collins JF, Baltz JH, Quin JA, et al. Five-year outcomes after on-pump and off-pump coronary-artery bypass. $N$ Engl J Med. 2017;377:623-32.

2. Lamy A, Devereaux PJ, Prabhakaran D, Taggart DP, Hu S, Straka Z, et al; CORONARY Investigators. Five-year outcomes after off-pump or on-pump coronary-artery bypass grafting. N Engl J Med. 2016;375:2359-68.

3. Cooper WA, O'Brien SM, Thourani VH, Guyton RA, Bridges CR, Szczech LA, et al. Impact of renal dysfunction on outcomes of coronary artery bypass surgery: results from the Society of Thoracic Surgeons National Adult Cardiac Database. Circulation. 2006;113:1063-70.

4. euroSCORE.org. euroSCORE: European System for Cardiac Operative Risk Evaluation. Available at: www.euroscore.org. Accessed March 23, 2018.

5. Miceli A, Bruno VD, Capoun R, Duggan SM, Romeo F, Angelini GD, et al. Mild renal dysfunction in patients undergoing cardiac surgery as a new risk factor for EuroSCORE. Heart. 2011;97:362-5

6. Miceli A, Bruno VD, Capoun R, Romeo F, Angelini GD, Caputo M. Occult renal dysfunction: a mortality and morbidity risk factor in coronary artery bypass grafting surgery. J Thorac Cardiovasc Surg. 2011;141:771-6.

7. Ueki C, Miyata H, Motomura N, Sakata R, Sakaguchi G, Akimoto T, et al. Offpump technique reduces operative mortality after elective coronary artery bypass grafting in patients with preoperative renal failure. J Thorac Cardiovasc Surg. 2018;156:976-83.

Access to The Journal of Thoracic and Cardiovascular Surgery Online is reserved for print subscribers!

Full-text access to The Journal of Thoracic and Cardiovascular Surgery Online is available for all print subscribers. To activate your individual online subscription, please visit The Journal of Thoracic and Cardiovascular Surgery Online, point your browser to http://www.mosby.com/jtcvs, follow the prompts to activate your online access, and follow the instructions. To activate your account, you will need your subscriber account number, which you can find on your mailing label (note: the number of digits in your subscriber account number varies from 6 to 10 ). See the example below in which the subscriber account number has been circled:

\section{Sample mailing label}

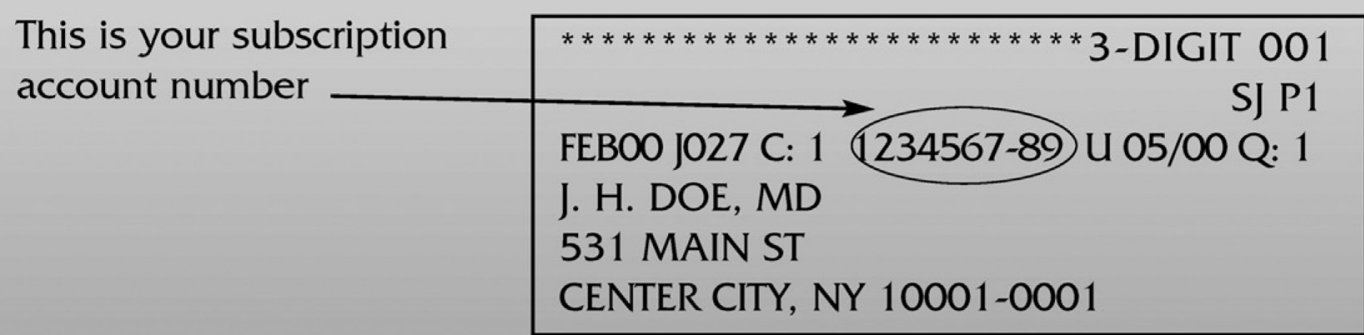

Personal subscriptions to The Journal of Thoracic and Cardiovascular Surgery Online are for individual use only and may not be transferred. Use of The Journal of Thoracic and Cardiovascular Surgery Online is subject to agreement to the terms and conditions as indicated online. 